\title{
SIMULTANEOUS AND SEQUENTIAL EXTRACTION PROTOCOLS AS TOOLS FOR DETERMINATION OF ZINC BIOAVAILABILITY IN DRIED ANAEROBIC SLUDGE
}

\author{
VLADIMÍR FRIŠTÁK, MICHAELA VALOVČIAKOVÁ, \\ MARTIN PIPÍŠKKA, JOZEF AUGUSTÍN
}

\author{
Department of Ecochemistry and Radioecology, Faculty of Natural Sciences, \\ University of SS. Cyril and Methodius in Trnava, Nám. J. Herdu 2, SK-917 01 Trnava, \\ Slovak Republic (vladimir.fristak@ucm.sk)
}

\begin{abstract}
Production of unsettleable sewage sludge with high water content is one of the problems of intensification of industrial activities and environmental protection. Sewage sludge with low toxic metals concentrations can be utilized as fertilizer and soil conditioner in agriculture. For determination of metal bioavailability, a wide range of extraction protocols and fractionation analyses can be used. We studied the distribution and quantified the leaching and bioavailability of zinc from dried anaerobic sludge by simultaneous, multi-step and three different sequential extraction protocols. For determination of zinc, the galvanostatic stripping chronopotentiometry (SCP) and electrothermal atomic absorption spectrometry (ETAAS) were used. The distribution of $\mathrm{Zn}$ in sequential extraction protocols was determined using a fivestep chemical fractionation procedures (BCR, Tessier and Van Hullebusch protocols). The potential bioavailability $\left(0.9 \% \mathrm{NaCl}, 0.1 \mathrm{~mol} / \mathrm{dm}^{3} \mathrm{HCl}, 0.1 \mathrm{~mol} / \mathrm{dm}^{3} \mathrm{HNO}_{3}, 0.1 \mathrm{~mol} / \mathrm{dm}^{3} \mathrm{CH}_{3} \mathrm{COOH}, 0.1 \mathrm{~mol} / \mathrm{dm}^{3}\right.$ $\mathrm{Na}_{2}$ EDTA, $0.1 \mathrm{~mol} / \mathrm{dm}^{3} \mathrm{CaCl}_{2}, 0.1 \mathrm{~mol} / \mathrm{dm}^{3} \mathrm{MgCl}_{2}, 0.1 \mathrm{~mol} / \mathrm{dm}^{3}\left(\mathrm{NH}_{4}\right)_{2} \mathrm{C}_{2} \mathrm{O}_{4} \cdot \mathrm{H}_{2} \mathrm{O}$ extraction) and pseudo total (aqua regia extraction and ETAAS analyses) content of $\mathrm{Zn}$ in sludge was determined. The amount of aqua regia extractable zinc in sludge samples was $650 \pm 12 \mathrm{mg} / \mathrm{kg}$ (d.w.). We found out that the zinc was extractable from anaerobic sludge in first hour of contact time for all tested agents. Zinc was extracted with highest efficiency by $0.1 \mathrm{~mol} / \mathrm{dm}^{3}\left(\mathrm{NH}_{4}\right)_{2} \mathrm{C}_{2} \mathrm{O}_{4} \cdot \mathrm{H}_{2} \mathrm{O}, 0.1 \mathrm{~mol} / \mathrm{dm}^{3} \mathrm{HCl}$ and $0.1 \mathrm{~mol} / \mathrm{dm}^{3} \mathrm{Na}_{2}$ EDTA. Sequential extraction protocols showed that the maximum extractable amount of zinc $126.3 \pm 2.6 \mathrm{mg} \mathrm{Zn} /$ $\mathrm{kg}$ d.w. was bound to organic matter and sulfides. High concentrations of zinc in residual fractions were leachable under extraction conditions of strong acids only.
\end{abstract}

Key words: anaerobic sludge, Zn, bioavailability, extraction procedures, galvanostatic stripping chronopotentiometry

\section{Introduction}

The amount of sewage sludge from wastewater treatment plants and a number of technological processes in the world are constantly increasing. Production of unsettleable sewage sludge with high water content is one of the problems of intensification of industrial activities and environmental protection. Sewage sludge with low toxic metals concentration can be utilized as fertilizer and soil conditioner in agriculture. Information about metal binding into sorption sites of sludges are limited for application of sludges into the soil. The ecological and toxicological effect of potentially toxic metals from sewage sludge on agro-ecosystem is directly related to their partitioning between mobile and complexed species in the highly heterogeneous soil system (MERRINGTON et al., 1997). Many factors influence this partitioning of toxic metals in soil amended with sludge including the soil and sludge characteristics. 
Thus, it is necessary to realize that for a safe use of sewage sludge as soil conditioner, the undesirable elements have to be removed, so reducing environmental contamination to a minimum.

For extraction of heavy metals from sewage sludges, a variety of single and sequential extraction techniques can be used. These techniques were recently reviewed by BABEL and DACERA (2006). However, owing to the wide range of extractants used in these extraction techniques, the results obtained were not comparable. In 1987, the Community Bureau of Reference (BCR) started a programme to harmonize the methodology used in sequential extraction schemes for determination of metals in soils and sediments (URE et al., 1993). The methodology was successfully applied to different types of sewage sludges (FUENTES et al., 2004). The type of applied sequential extraction scheme can lead to the anomalies in the results, as sequential extraction schemes are greatly influenced by the type of extractants used, the operating conditions ( $\mathrm{pH}$, contact time and temperature) and the sequence in which the extractions steps are applied. VAN HULLEBUSCH et al. (2005) compared the sequential extraction procedure by TESSIER et al. (1979), the procedure according to STOVER et al. (1976), the BCR protocol for fractionation of $\mathrm{Co}, \mathrm{Ni}, \mathrm{Cu}, \mathrm{Zn}, \mathrm{Mn}$ and Fe.

The main aim of our paper was to describe distribution, leaching and bioavailability of zinc from dried anaerobic sludge by simultaneous, multi-step and sequential extraction protocols. Owing to the scarcity of data associated with the characterization and fractionation of heavy metals in anaerobic sludge from municipal wastewater treatment plants, this paper produces a useful data for an area disposal for this type of waste as soil conditioner.

\section{Materials and method}

\subsection{Sample}

Anaerobic digested sludge was obtained from mechanical-biological waste water treatment plant (WWTP) in Zeleneč (Slovak Republic). After washing in deionised water, sludge biomass was oven dried at $105^{\circ} \mathrm{C}$ for $48 \mathrm{~h}$, ground, sieved and stored in closed bottles at laboratory temperature. For extraction experiments fraction $<2 \mathrm{~mm}$ was used.

\subsection{Total (aqua regia extractable) zinc fraction}

The pseudototal concentration of zinc in sludge samples was estimated by aqua regia extraction in triplicate. Extracts were analysed by atomic absorption spectrometry with electrothermal atomization (ETAAS) device Shimadzu AA-6300 (USA) with electrothermal atomizers Shimadzu GFA-EX7i using an automatic dispenser Shimadzu ASC 6100 and background correction method of Smith-Hieftje, after microwave digestion of the samples by the Multiwave system MW 3000 (Anton Paar GmbH, AUS). 


\subsection{Single-step extractable zinc}

Leachable and bioavailable fractions of zinc from anaerobic sludge were obtained after simultaneous extractions with variable set of extractants. Extraction experiments were carried out by suspending of dried anaerobic sludge $\left(10 \mathrm{~g} / \mathrm{dm}^{3} \mathrm{~d} . \mathrm{w}\right.$. $)$ in $10 \mathrm{~cm}^{3}$ of reagents: deionized water, rain water ( $\mathrm{pH} 5.34$; conductivity $45.6 \mu \mathrm{S} / \mathrm{cm}), 0.9 \% \mathrm{NaCl}$, $0.1 \mathrm{~mol} / \mathrm{dm}^{3} \mathrm{HCl}, 0.1 \mathrm{~mol} / \mathrm{dm}^{3} \mathrm{HNO}_{3}, 0.1 \mathrm{~mol} / \mathrm{dm}^{3} \mathrm{CH}_{3} \mathrm{COOH}, 0.1 \mathrm{~mol} / \mathrm{dm}^{3}$ $\mathrm{Na}_{2}$ EDTA, $0.1 \mathrm{~mol} / \mathrm{dm}^{3} \mathrm{CaCl}_{2}, 0.1 \mathrm{~mol} / \mathrm{dm}^{3} \mathrm{MgCl}_{2}, 0.1 \mathrm{~mol} / \mathrm{dm}^{3}\left(\mathrm{NH}_{4}\right)_{2} \mathrm{C}_{2} \mathrm{O}_{4} \cdot \mathrm{H}_{2} \mathrm{O}$. Samples of the sludge were extracted in five extraction steps $\left(1 \mathrm{~h}, 150 \mathrm{~min}^{-1}, 22^{\circ} \mathrm{C}\right)$. The supernatant after centrifugation (5 min, $4500 \mathrm{~min}^{-1}$ ) was isolated from the sediment after each extraction step. Sediment was used in the next extraction step. All experiments were carried out in triplicates.

\subsection{Sequential extractable zinc}

For investigation of the distribution of zinc among different fractions of anaerobic sludge, the following extraction protocol was used: 1. Modified extraction protocol by TESSIER (1979) for analysis of soil and sediments (Tab. 1), 2. Extraction protocol for sewage sludge according to VAN HULLEBUSCH et al. (2005) (Tab. 2), 3. BCR extraction protocol (Tab. 3). In all cases, $1 \mathrm{~g}$ of dried anaerobic sludge sample was used.

Table 1. Extraction conditions of modified sequential extraction protocol of dried anaerobic sludge (TESSIER, 1979).

\begin{tabular}{cccc}
\hline \multirow{2}{*}{ Fraction } & \multicolumn{3}{c}{ Extraction conditions } \\
\cline { 2 - 4 } Exchangeable & $\begin{array}{c}8 \mathrm{ml} \mathrm{MgCl} \\
\left(1 \mathrm{~mol} / \mathrm{dm}^{3}, \mathrm{pH} 7.0\right)\end{array}$ & $1 \mathrm{~h}$ & $20{ }^{\circ} \mathrm{C}$ \\
$\begin{array}{c}8 \mathrm{ml} \mathrm{NaOAc} \\
\text { Carbonates }\end{array}$ & $5 \mathrm{~h}$ & $20{ }^{\circ} \mathrm{C}$ \\
$\begin{array}{c}\left(1 \mathrm{~mol} / \mathrm{dm}^{3}, \mathrm{pH} 7.0\right) \\
\text { Iron and manganese } \\
\text { oxides }\end{array}$ & $\begin{array}{c}8 \mathrm{ml} \mathrm{NH} \mathrm{NH}_{2} \mathrm{OH} . \mathrm{HCl} \\
\left(0,1 \mathrm{~mol} / \mathrm{dm}^{3}, \mathrm{pH} 3.0\right)\end{array}$ & $16 \mathrm{~h}$ & $35^{\circ} \mathrm{C}$ \\
$\begin{array}{c}\text { Organic matter and } \\
\text { sulphides } \\
\text { Residual }\end{array}$ & $8 \mathrm{ml} \mathrm{H}_{2} \mathrm{O}_{2}(30 \%)$ & $5 \mathrm{~h}$ & $35^{\circ} \mathrm{C}$ \\
\hline
\end{tabular}

${ }^{*}$ microwave conditions (p $20 \mathrm{Bar}, \mathrm{T}_{\max } 180^{\circ} \mathrm{C}$ )

\subsection{Treatment of extracts and galvanostatic stripping chronopotentiometry}

Zinc in extracts was determined by galvanostatic stripping chronopotentiometry on macroporous electrode E104 L using electrochemical analyser EcaFlow model GLP 150 (Istran, Ltd., Bratislava, Slovakia). $5 \mathrm{ml}$ of extracts was added to flask with 20-30 $\mathrm{ml} 0.1 \mathrm{~mol} / \mathrm{dm}^{3} \mathrm{HCl}$ and $0.5 \mathrm{ml} 0.01 \mathrm{~mol} / \mathrm{dm}^{3} \mathrm{KMnO}_{4}$. The solution was heated to 80 - 
$95{ }^{\circ} \mathrm{C}$ for 5-10 min. Oxalic acid was added to reduce the excess of permanganate. The volume of samples was adjusted to $50 \mathrm{ml}$ with $0.1 \mathrm{~mol} / \mathrm{dm}^{3} \mathrm{HCl}$. Solid particles were removed by filtering, centrifugation or sedimentation.

Table 2. Extraction conditions of modified sequential extraction protocol of dried anaerobic sludge (VAN HULLEBUSCH et al., 2005).

\begin{tabular}{|c|c|c|c|}
\hline \multirow{2}{*}{ Fraction } & \multicolumn{3}{|c|}{ Extraction conditions } \\
\hline & Extracting agent & Reaction time & Temperature \\
\hline Exchangeable & $\begin{array}{l}10 \mathrm{ml} \mathrm{CH}_{3} \mathrm{COONH}_{4} \\
\left(1 \mathrm{~mol} / \mathrm{dm}^{3}, \mathrm{pH} 7.0\right)\end{array}$ & $1 \mathrm{~h}$ & $20^{\circ} \mathrm{C}$ \\
\hline Carbonates & $\begin{array}{c}10 \mathrm{ml} \mathrm{CH}{ }_{3} \mathrm{COOH} \\
\left(1 \mathrm{~mol} / \mathrm{dm}^{3}, \mathrm{pH} 5.5\right)\end{array}$ & $1 \mathrm{~h}$ & $20^{\circ} \mathrm{C}$ \\
\hline $\begin{array}{l}\text { Organic matter } \\
\text { and sulphides }\end{array}$ & $5 \mathrm{ml} \mathrm{H}_{2} \mathrm{O}_{2}(30 \%, \mathrm{pH} 2.0)$ & $3 \mathrm{~h}$ & $35^{\circ} \mathrm{C}$ \\
\hline Residual & $10 \mathrm{ml} \mathrm{HCl} / \mathrm{HNO}_{3}(3: 1)$ & $26 \mathrm{~min}$ & $180{ }^{\circ} \mathrm{C} *$ \\
\hline
\end{tabular}

${ }^{*}$ microwave conditions (p $20 \mathrm{Bar}, \mathrm{T}_{\max } 180^{\circ} \mathrm{C}$ )

Table 3. Extraction conditions of BCR modified extraction procedure of dried anaerobic sludge (VAN HULLEBUSCH et al., 2005).

\begin{tabular}{|c|c|c|c|}
\hline \multirow{2}{*}{ Fraction } & \multicolumn{3}{|c|}{ Extraction conditions } \\
\hline & Extracting agent & Reaction time & Temperature \\
\hline Exchangeable & $\begin{array}{c}40 \mathrm{ml} \mathrm{CH} \mathrm{COOH}_{3} \\
\left(0,11 \mathrm{~mol} / \mathrm{dm}^{3}, \mathrm{pH} 7.0\right)\end{array}$ & $16 \mathrm{~h}$ & $20{ }^{\circ} \mathrm{C}$ \\
\hline $\begin{array}{c}\text { Iron and } \\
\text { manganese oxides }\end{array}$ & $\begin{array}{c}40 \mathrm{ml} \mathrm{NH} \mathrm{N}_{2} \mathrm{OH} . \mathrm{HCl} \\
\left(0,5 \mathrm{~mol} / \mathrm{dm}^{3}, \mathrm{pH} 1.5\right)\end{array}$ & $16 \mathrm{~h}$ & $20{ }^{\circ} \mathrm{C}$ \\
\hline $\begin{array}{l}\text { Organic matter } \\
\text { and sulphides }\end{array}$ & $\begin{array}{c}20 \mathrm{ml} \mathrm{H}_{2} \mathrm{O}_{2} \\
(30 \%, \mathrm{pH} 2.0) \\
50 \mathrm{ml} \mathrm{CH} \mathrm{COONH}_{4} \\
\left(1 \mathrm{~mol} / \mathrm{dm}^{3}, \mathrm{pH} 2.0\right)\end{array}$ & $16 \mathrm{~h}$ & $20{ }^{\circ} \mathrm{C}$ \\
\hline Residual & $10 \mathrm{ml} \mathrm{HCl} / \mathrm{HNO}_{3}$ & $26 \mathrm{~min}$ & $180^{\circ} \mathrm{C}$ \\
\hline
\end{tabular}

${ }^{*}$ microwave conditions (p $20 \mathrm{Bar}, \mathrm{T}_{\max } 180^{\circ} \mathrm{C}$ )

\section{Results and discussion}

\subsection{Pseudototal zinc content}

Concentration of mobile zinc in the sewage sludge is important for using the sludge as soil conditioner and fertilizer. In our paper, pseudototal zinc content in anaerobic sewage sludge refers to the fraction of aqua regia soluble. The amount of zinc in sludge samples was $649.5 \pm 12 \mathrm{mg} / \mathrm{kg}$ (d.w.). This digestion is considered adequate for analysing total-recoverable heavy metals in soils (MEERS et al., 2007). Residual elements that are not released by aqua regia digestion are mostly bound to 
silicate minerals and are considered unimportant for estimating the mobility and behaviour of metals (NISKAVAARA et al., 1997). Concentration of zinc determined by ETAAS was comparable with concentration determined by stripping chronopotentiometry.

\subsection{Single-step and multi-step extraction protocols}

It has been reported that the addition of different amendments to soil changes soil reaction and consequently the mobility and bioavailability of potentially toxic metals (HETTIARACHCHI and PIERZYNSKI, 2004). It is widely recognized that not all chemical forms of potentially chemical metals interact with living organisms in the same manner and that their potential bioavailability has to be considered when assesing soil pollution. However, no single method is recognized universally (TICA et al., 2011). Simultaneous and multi-step extractions are one of possible techniques for quantification of leachable elements from soil, sediments and sludge.

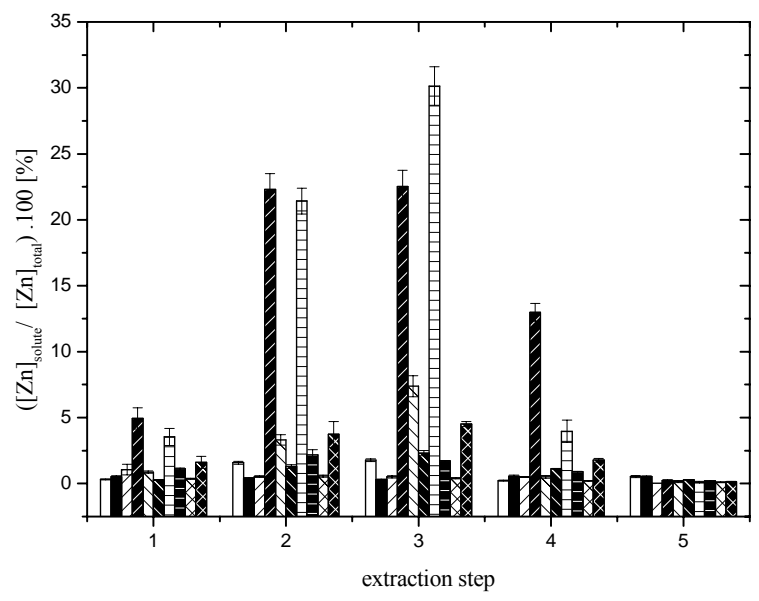

Fig. 1. Efficiency of five-step extraction protocols of zinc (\%) from the anaerobic sludge $\left(100 \mathrm{~g} / \mathrm{dm}^{3}\right)$. Extraction conditions: $\mathrm{t}_{1 \text { step }}=1 \mathrm{~h}, 22{ }^{\circ} \mathrm{C}, 150 \mathrm{~min}^{-1}$, extractants: deionized water $(\square)$,rain water $(\square), 0.9 \%$ $\mathrm{NaCl}(\mathbb{Z}), 0.1 \mathrm{~mol} / \mathrm{dm}^{3} \mathrm{HCl}(\mathbb{Z}), 0.1 \mathrm{~mol} / \mathrm{dm}^{3} \mathrm{HNO}_{3}(\mathbb{W}), 0.1 \mathrm{~mol} / \mathrm{dm}^{3} \mathrm{CH}_{3} \mathrm{COOH}(\mathbf{w}), 0.1 \mathrm{~mol} / \mathrm{dm}^{3}$ $\mathrm{Na}_{2}$ EDTA (口), $0.1 \mathrm{~mol} / \mathrm{dm}^{3} \mathrm{CaCl}_{2}(\Xi), 0.1 \mathrm{~mol} / \mathrm{dm}^{3} \mathrm{MgCl}_{2}(\boldsymbol{\nabla}), 0.1 \mathrm{~mol} / \mathrm{dm}^{3}\left(\mathrm{NH}_{4}\right)_{2} \mathrm{C}_{2} \mathrm{O}_{4} \cdot \mathrm{H}_{2} \mathrm{O}(\boldsymbol{\nabla})$. All experiments were realised in triplicates. Error bars represent standard deviation of the mean $( \pm \mathrm{SD})$

As extracting agents in extraction procedures, strong acid and their mixtures $\left(\mathrm{HNO}_{3}, \mathrm{H}_{2} \mathrm{SO}_{4}, \mathrm{HCl}\right.$, aqua regia), neutral solution of salts $\left(\mathrm{CaCl}_{2}, \mathrm{MgCl}_{2}, \mathrm{NaCl}\right)$, pending puffer and complex-forming agents $\left(\mathrm{Na}_{2} \mathrm{EDTA}\right)$ can be used (MEERS et al., 2007). The extraction protocols used in our paper were initially developed for the assessment of zinc bioavailability but they are also used for the assessment of potentially toxic metals released from the sludge enriched soils and their consequent potential availability to all soil organisms (McLAUGHLIN et al., 2000). In our paper, 10 extracting agents for determination of mobile fraction of zinc in anaerobic digested sludge were used. We found out that zinc is extractable from anaerobic sludge in the 
first hour of contact time. Zinc was extracted with highest efficiency by $0.1 \mathrm{~mol} / \mathrm{dm}^{3}$ $\left(\mathrm{NH}_{4}\right)_{2} \mathrm{C}_{2} \mathrm{O}_{4} \cdot \mathrm{H}_{2} \mathrm{O}, 0.1 \mathrm{~mol} / \mathrm{dm}^{3} \mathrm{HCl}$ and $0.1 \mathrm{~mol} / \mathrm{dm}^{3} \mathrm{Na}_{2}$ EDTA. Sediments of all extraction protocols were extracted subsequently 5 times. The efficiency of agents increases to the third step of extraction process (Fig. 1). Extraction efficiency of used extracting agents decreases in order: $0.1 \mathrm{~mol} / \mathrm{dm}^{3} \mathrm{HCl}(408.82 \pm 9.23 \mathrm{mg} / \mathrm{kg})>$ $0.1 \mathrm{~mol} / \mathrm{dm}^{3} \mathrm{Na}_{2}$ EDTA $(383.12 \pm 7.14 \mathrm{mg} / \mathrm{kg})>0.1 \mathrm{~mol} / \mathrm{dm}^{3} \mathrm{HNO}_{3}(81.72 \pm 3.54$ $\mathrm{mg} / \mathrm{kg})>0.1 \mathrm{~mol} / \mathrm{dm}^{3}\left(\mathrm{NH}_{4}\right)_{2} \mathrm{C}_{2} \mathrm{O}_{4} \cdot \mathrm{H}_{2} \mathrm{O}(77.87 \pm 3.27 \mathrm{mg} / \mathrm{kg})>0.1 \mathrm{~mol} / \mathrm{dm}^{3} \mathrm{CaCl}_{2}$ $(36.54 \pm 1.88 \mathrm{mg} / \mathrm{kg})>0.1 \mathrm{~mol} / \mathrm{dm}^{3} \mathrm{CH}_{3} \mathrm{COOH}(36.12 \pm 1.87 \mathrm{mg} / \mathrm{kg})>$ deionized water $(26.22 \pm 1.41 \mathrm{mg} / \mathrm{kg})>$ rain water $(24.54 \pm 1.71 \mathrm{mg} / \mathrm{kg})>0.9 \% \mathrm{NaCl}(16.89 \pm$ $1.03 \mathrm{mg} / \mathrm{kg})>0.1 \mathrm{~mol} / \mathrm{dm}^{3} \mathrm{MgCl}_{2}(14.32 \pm 0.98 \mathrm{mg} / \mathrm{kg})$. Nonextractable zinc fraction was electrochemically quantified in residual sediment after the fifth step of extraction protocol and aqua regia digestion. The sum of total extractable zinc and nonextractable zinc corresponded to the concentration detected by ETAAS in the initial characterization studies (as can be seen in chapter 3.1).

\subsection{Fraction analyses of zinc by sequential extraction protocols}

Results of the three extraction protocols for the zinc concentration are presented in Tab. 5 and Fig. 2. For each extraction, three samples were simultaneously analysed to determine the precision of the measurements. Tab. 4 shows that all extraction protocols provide a satisfactory recovery of zinc from anaerobic sludge. The sum of four steps and of the residue expressed as percentages of the total concentration varies from 99 to $101 \%$. The reproducibility of the Tessier and BCR protocols is higher than the reproducibility of the Stover extraction scheme (RUDD et al., 1988).

Table 4. Comparation of $\mathrm{Zn}$ content in dried sludge estimated by Tessier, Van Hullebush and BCR extraction protocols (mean $\pm \% \mathrm{SD}, \mathrm{n}=3$ ).

\begin{tabular}{cccc}
\hline & Tessier protocol & $\begin{array}{c}\text { Van Hullebusch } \\
\text { protocol }\end{array}$ & BCR protocol \\
\hline$\Sigma[\mathbf{m g} / \mathbf{k g}]$ & $656.6( \pm 1.5 \%)$ & $650.1( \pm 1.1 \%)$ & $645.9( \pm 0.7 \%)$ \\
$\mathbf{M}_{\mathbf{T}}[\mathbf{m g} / \mathbf{k g}]$ & $649.5( \pm 1.9 \%)$ & $649.5( \pm 1.9 \%)$ & $649.5( \pm 1.9 \%)$ \\
Recovery [\%] & 101 & 100 & 99 \\
\hline
\end{tabular}

$\Sigma$ - the sum of all extraction steps; $\mathrm{M}_{\mathrm{T}}$ - the pseudo total zinc concentration.

Neutral salt extraction efficiency depends on the type of cation (different affinity to surface binding sites) and decreases in the order $\mathrm{H}^{+}>\mathrm{Ca}^{2+}>\mathrm{Mg}^{2+}>\mathrm{Na}^{+}=\mathrm{NH}^{4+}$ (VOJTEKOVÁ and KRAKOVSKÁ, 2006). In our paper, extraction with ion exchangeable agents $\left(\mathrm{MgCl}_{2}, \mathrm{CH}_{3} \mathrm{COONH}_{4}, \mathrm{CH}_{3} \mathrm{COOH}\right)$ confirmed the sorption characteristics of $\mathrm{Zn}$ in concentrations $2.2 \pm 0.3 \mathrm{mg} / \mathrm{kg}$ (Tessier protocol), $15.8 \pm 0.6$ $\mathrm{mg} / \mathrm{kg}$ (Van Hullebusch protocol) and $21.5 \pm 0.5 \mathrm{mg} / \mathrm{kg}$ (BCR protocol). The comparison of leaching data between the exchangeable/ carbonates fraction from the BCR procedure, the sum of exchangeable and carbonates fractions from the modified Tessier protocol and the sum of exchangeable and carbonates fractions from the Van Hullebusch protocol shows some interesting trends. The amount of zinc that was 
extracted in these fractions is in the same order of magnitude between each extraction protocol. Extraction of sludge with $\mathrm{MgCl}_{2}$ has a lower efficiency of zinc leaching attributed to lower solubilisation of organic components on sludge surface (URE et al., 1995). Solution of $\mathrm{CH}_{3} \mathrm{COONH}_{4}$ dissolves a considerable amount of $\mathrm{CaCO}_{3}, \mathrm{MgCO}_{3}$, $\mathrm{BaCO}_{3}, \mathrm{CaSO}_{4}$ and can act on oxide-metal (Mn, Fe) layers on the sludge surface (VOJTEKOVÁ and KRAKOVSKÁ, 2006). Reducible fraction represents the content of zinc bound to $\mathrm{Fe} / \mathrm{Mn}$ oxides that are released if matrix of sludge is subjected to reductive conditions. Iron and manganese oxides are relatively scarce in this organicrich sludge (VAN HULLEBUSCH et al., 2005). Leachable zinc into acetic acid and its salts can be regarded as almost quantitatively, without dissolving the organic fraction, oxides of Mn, Fe and aluminum silicate minerals (WILBER and HUNTER, 1979).

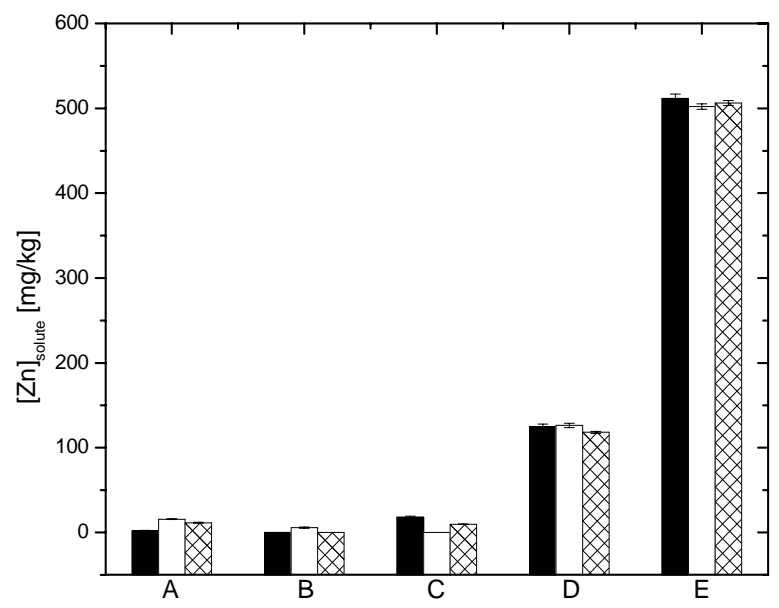

Fig. 2. Zinc partitioning profile of anaerobic sludge for exchangeable fraction (A), fraction of carbonates (B), fraction of $\mathrm{Fe}$ and $\mathrm{Mn}$ oxides (C), fraction of organic matter and sulphides (D), residual fraction (E)

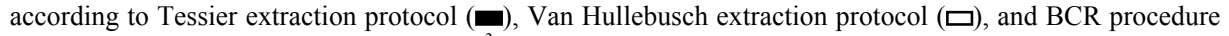
(四) $\left(\right.$ mean $\left.\pm \mathrm{SD}, \mathrm{n}=3, \mathrm{LOD}=0.15 \mu \mathrm{g} / \mathrm{dm}^{3}\right)$.

Sequential extraction by Tessier confirmed the presence of $\mathrm{Zn}$ bound to this fraction, respectively. Concentration of extracted zinc from sludge according to the Van Hullebusch protocol was below the limit of detection of equipments used. We found that the maximum extractable concentration of zinc $126.3 \pm 2.6 \mathrm{mg} \mathrm{Zn} / \mathrm{kg}$ d.w. was bound to organic matter and sulfides (Fig. 2). Compared to the other two protocols, we found out that the fraction of zinc bound to organic matter and sulphides is major bioavailable fraction of zinc from anaerobic sludge. High concentrations of zinc in residual fractions are leachable under radical extraction conditions of strong acids only. The contents of $\mathrm{Zn}$ in the residual fractions obtained from the three sequential extraction protocols after exposure and microwave digestion are comparable to each other. NEMATI et al. (2009) determined reducible fraction of zinc to $39.9 \pm 3.5 \mathrm{mg} \mathrm{Zn} \mathrm{/} \mathrm{kg}$ sewage sludge, oxidizable fraction of zinc bound to organic matter and sulfides in the amount of $58.1 \pm 0.2 \mathrm{mg} / \mathrm{kg}$ of sludge. RUDD et al. (1988) showed that zinc sulfides precipitates are relatively difficult to extract in the sulfides 
fraction of extraction protocols. In this respect, RUDD et al. (1988) suggested that it can be more appropriate to classify the sulfides and residual fractions as a single phase.

\section{Conclusions}

In our paper, we found out that amount of aqua regia extractable zinc in sludge samples was $649.5 \pm 12 \mathrm{mg} / \mathrm{kg}$ (d.w.). Zinc was extractable from anaerobic sludge in first hour of contact time in extraction by $0.9 \% \mathrm{NaCl}, 0.1 \mathrm{~mol} / \mathrm{dm}^{3} \mathrm{HCl}, 0.1 \mathrm{~mol} / \mathrm{dm}^{3}$ $\mathrm{HNO}_{3}, 0.1 \mathrm{~mol} / \mathrm{dm}^{3} \mathrm{CH}_{3} \mathrm{COOH}, 0.1 \mathrm{~mol} / \mathrm{dm}^{3} \mathrm{Na}_{2}$ EDTA, $0.1 \mathrm{~mol} / \mathrm{dm}^{3} \mathrm{CaCl}_{2}, 0.1$ $\mathrm{mol} / \mathrm{dm}^{3} \mathrm{MgCl}_{2}$ and $0.1 \mathrm{~mol} / \mathrm{dm}^{3}\left(\mathrm{NH}_{4}\right)_{2} \mathrm{C}_{2} \mathrm{O}_{4} \cdot \mathrm{H}_{2} \mathrm{O}$. Zinc was extracted with highest efficiency by $0.1 \mathrm{~mol} / \mathrm{dm}^{3} \mathrm{HCl}(408.82 \pm 9.23 \mathrm{mg} / \mathrm{kg}), 0.1 \mathrm{~mol} / \mathrm{dm}^{3} \mathrm{Na}_{2}$ EDTA $(383.12$ $\pm 7.14 \mathrm{mg} / \mathrm{kg})$ and $0.1 \mathrm{~mol} / \mathrm{dm}^{3} \mathrm{HNO}_{3}(81.72 \pm 3.54 \mathrm{mg} / \mathrm{kg})$. Sequential extraction protocols showed that the maximum extractable concentration of zinc $126.3 \pm 2.6 \mathrm{mg}$ $\mathrm{Zn} / \mathrm{kg}$ d.w. was bound to organic matter and sulphides. High concentrations of zinc in residual fractions were leachable under extraction conditions by strong acids only. The contents of $\mathrm{Zn}$ in the residual fractions obtained from the BCR, Tessiers and Van Hullebuschs sequential extraction protocols after exposure and microwave digestion were comparable to each other. Data of characterization and fractionation of zinc in anaerobic sludge from municipal wastewater treatment plants are useful for assessment of zinc mobility in sewage sludge as soil amendment.

\section{References}

BABEL, S., DACERA, D.D.M.: Heavy metal removal from contaminated sludge for land application. J. Waste Manag., 26, 2006, 988-1004.

FUENTES, A., LlORENS, M., SAEZ, J., SOLER, A., AGUILAR, M., ORTUNO, F.: Phytotoxicity and heavy metals speciation of stabilized sewage sludges. J. Hazard. Mater., 108, 2004, 161-169.

HETTIARACHCHI, R.M., PIERZYNSKI, R.M.: Soil lead bioavailability and in situ remediation of lead-contaminated soils: A review. Environ. Prog., 23, 2004, 78-93.

McLAUGHLIN,M.J., HAMON, R.E., McLAREN, R.G., SPEIR, T.W., ROGERS, S.L.: A bioavailability-based rationale for controlling metal and metalloid contamination of agricultural land in Australia and New Zealand. Aust. J. Soil Res., 38, 2000, 1037-1086.

MEERS, E., LAING, D, D., UNAMUNO, V., RUTTENS, A., VANGRONSVELD, J., TACK, F.M.G., VERLOO, M.G.: Comparison of cadmium extractability from soils by commonly used single extraction protocols. Geoderma, 141, 2007, 247259.

MERRINGTON, G., WINDER, L., GREEN. I.: The bioavailability of Cd and Zn from soils amended with sewage sludge to winter wheat and subsequently to the grain aphid Sitobion avenae. Sci. Tot. Environ., 205, 1997, 245-254.

NEMATI, K., BAKAR, N.K.A., SOBHANZADEH, E., ABAS, M.R.: A modification of BCR sequential extraction procedure to investigate the potential mobility of copper and zinc in shrimp aquaculture sludge. J. Microchem., 92, 2009, 165-169. 
NISKAVAARA, H., REIMANN, C., CHEKUSHIN, V., KASHULINA, G.: Seasonal variability of total and easily leachable element contents in topsoils $(0-5 \mathrm{~cm})$ from eight catchments in the European Arctic (Finland, Norway and Russia). Environ. Pollut., 96, 1997, 261-274.

RUDD, T., CMAPBELL, J.A., LESTER, N.J.: The use of model compounds to elucidate metal forms in sewage sludge. Environ. Pollut., 50, 1988, 225

STOVER, R.C., SOMMERS, L.E., SILVIERA, D.J.: Evaluation of metals in wastewater sludge. J. Water Pollut., 48, 1976, 2165.

TESSIER, A., CAMPBELL, P.G.C., BISSON, M.: J. Anal. Chem., 51, 1979, 844.

TICA, D., UDOVIC, M., LESTAN, D.: Immobilisation of potentially toxic metals using different soil amendments. Chemosphere, 85, 2011, 577-583.

URE, A.M., DAVIDSON, C.M., THOMAS, R.P.: Single and sequential extraction schemes for trace metal speciation in soil and sediment. Tech. Instrum. Anal. Chem., 17, 1995, 505-523.

URE, A.M., QUEVAUVILlER, P., MUNTAU, H., GRIEPINK, B.: Speciation of Heavy Metals in Soils and Sediments. An Account of the Improvement and Harmonization of Extraction Techniques Undertaken Under the Auspices of the BCR of the Commission of the European Communities. Int. J. Environ. Anal. Chem., 51, 1993, 1-4.

VAN HULLEBUSCH, E.D., UTOMO, S., ZANDVOORT, M.H., LENS, P.N.L.: Comparison of three sequential extraction procedures to describe metal fractionation in anaerobic granular sludges. Talanta, 65, 2005, 549-558.

VOJTEKOVÁ, V., KRAKOVSKÁ, E.: Frakcionačná analýza sedimentov- limitácie selektivity sekvenčného lúhovania. Chem. Lett., 100, 2006, 1096-1104 (In Slovak).

WILBER, W.G., HUNTER, J.V.: The impact of urbanization on the distribution of heavy metals on bottom sediments of the Sadlle River. J. Water Resour., 15, 1979, 790-799. 